\title{
ÉTICA DA PAISAGEM
}

João Rocha*

RESUMO: A partir da figura paisagem, presente ao longo da obra de Maria Gabriela Llansol, este trabalho visa extrair a noção de Ética da paisagem. Para isso, tomou-se como suporte teórico os textos de Eduardo Viveiros de Castro, Débora Danowski, Michel Serres, Jacques Lacan e Giorgio Agamben.

PALAVRAS-CHAVE: Maria Gabriela Llansol; Ética; Paisagem; Biogaia; Palavra-muda
* jarochabr@yahoo.com.br

Doutor em Teoria da Literatura e Literatura Comparada pelo Programa Estudos Literários da UFMG

RÉSUMÉ: À partir de la figure paysage, présente chez Maria Gabriela Llansol, ce travail vise à extraire la notion d'Éthique $d u$ paysage. On a pris comme supporte théorique les textes d'Eduardo Viveiros de Castro, Débora Danowski, Michel Serres, Jacques Lacan et Giorgio Agamben.

MOT-CLÉS : Maria Gabriela Llansol ; Éthique ; Paysage ; Biogée ; Palavra-muda 
"Só a escrita me liga à terra."

Contos do mal errante, Maria Gabriela Llansol

"state of emergency: how beautiful to be state of emergency: is where I want to be".

Jöga, Björk

Tudo no mundo escreve. A brisa do mar, as linhas das montanhas, a curva do céu. $\mathrm{O}$ vale, o leito dos rios, a aridez das pedras, o horizonte sublinhado pelo voo de um pássaro, o chão. O alfabeto das águas ainda não foi desvendado, nem a sintaxe das palavras de amor. Antes das palavras que conhecemos, havia o toque, havia o corpo com suas letras indecifráveis, havia a retidão do olhar de um felino a mostrar que nossa língua é só mais uma dentre as muitas que habitam o mundo. Na força imóvel das árvores, que cres cem em direção ao infinito, sem nunca tocá-lo, no silêncio dos passos de uma onça espreitando sua presa, inscreve-se a convicção de que Babel não é somente um mito para a construção das línguas dos homens, mas a certeza de que a paisagem também escreve.

Talvez possamos marcar nesse mito o começo de um caminho que levou o homem para fora da paisagem, que o levou a pensar que poderia ter a linguagem. A partir de Babel, melhor seria dizer da leitura que se fez do mito, o homem começa a pensar a paisagem como metáfora, como "tudo aquilo que se vê", concebendo-a como "um espaço humanizado, pelo olhar, pela habitação vivencial e pela habitação estética." Nesse processo narcísico de humanização da paisagem - sua metaforização -, o homem acredita estar mais próximo de realizar o seu sonho, o sonho de que tem a linguagem ${ }^{2}$. É nessa direção que Buescu trabalha a noção de paisagem literária. Para ela, "dizer que a paisagem literária representa a natureza será certamente verdade, no contexto, se compreendermos que natureza é, como sempre foi, um acontecimento humano, um acontecimento perante a consciência do humano." ${ }^{3}$ Nesse caminho que marca a natureza como um acontecimento humano, intensificado e disseminado, sobretudo, a partir do Iluminismo, e lê, portanto, o mito de Babel somente como a confusão das línguas dos homens; ou ainda somente o sentido de posse escrito no sonho de Llansol - "o sonho de que temos a linguagem” -, o homem só caminha para dentro de si e leva consigo a certeza de que está completamente apartado da paisagem. Porém, se tomarmos esse caminho que já vem sendo traçado há milênios, somos obrigados a nos prender nas malhas da criação do humano, ou seja, ficamos do lado de fora, como se não fizéssemos parte da natureza, como se ela não fosse o fora, o que sempre esteve lá e que atravessa o humano, permitindo-nos olhar para além de nós mesmos. Em outro caminho, podemos ler de outra maneira o sonho escrito por Llansol de que o que temos é somente a linguagem ${ }^{4}$ e que mesmo assim não a temos completamente, porque o sonho
1. BUESCU. Paisagem literária: imanência e transcendência, p. 10.

2. LLANSOL. “O sonho de que temos a linguagem".

3. BUESCU. Paisagem literária: imanência e transcendência, p. 17

4. Cf. BRANCO. “A pedra dura ao luar - O caderno branco". 
5. LLANSOL. “O sonho de que temos a linguagem", p. 17. inscreve-se, justamente, pelo fato de que é pela linguagem, somente por ela, que podemos entrar onde teimamos em manter distância, ou seja, na paisagem. Esse lugar guarda o sonho de uma outra leitura do mito de Babel que se inscreve, em segredo, nestas palavras de Llansol:

Sonho com o dia em que a presença que de nós ficará dos textos não será a do nome próprio. Em que os signos de nossa travessia serão destroços, toques de leveza [...].

Os poetas deixarão de submeter-se à poesia. Quem escreve irá além da mágoa. Os animais, fascinados pela benevolência do Buda, sensata e moderadamente, indicam o pacto de bondade que a todos nos une. Os homens saem de sua identidade. E o texto arrasta-nos para os lugares da linguagem onde seremos seres de fulgor, indeléveis e diáfanos. ${ }^{5}$

Com essas palavras de Llansol, escrevo o sonho que me guiará nestas páginas: o sonho de conceber a literatura como um suporte por onde deslizam, não somente as paisagens criadas pelos homens, mas aquelas escritas pelas penas dos pássaros, o sulco das rochas, os pelos e couros das bestas. $\mathrm{O}$ sonho de ler a literatura como o lugar de passagem daquilo que restou em silêncio nas ruínas de Babel: a paisagem inumana e, no entanto, demasiado humana, do homem.
A literatura encerra em seu corpo algo de apocalíptico, seja pela potência de revelação que sustenta, seja porque é atravessada pela morte. O que ela nos conta, inscreve-se no litoral do mundo e, portanto, a possibilidade do fim é sempre iminente. Mas, por situar-se no litoral, o começo também lhe é precioso Sua força apocalíptica também advém de sua estrutura de abismo, ou seja, do fracasso da relação entre as palavras e as coisas, pois a literatura faz ressoar o eco incessante das ruínas de Babe e, com ele, a certeza, perturbadora, de que não temos a linguagem $^{6}$. Sua potência de apocalipse é resultado das marcas de uma maldição: transmitir o que excede os limites do próprio corpo. Por ser maldita ela deve ser bem dita, palavra por palavra, letra a letra, para que possa, a todo momento, nascer e morrer... para nascer de novo... e morrer, em um movimento infinito.

Destruir, ela diz ${ }^{7}$, pois, segundo Duras, literatura e escrita são comparáveis à caça pré-histórica de quando nenhuma palavra tinha sido, ainda, escrita. Uma força, portanto, que levantou os homens, um apetite de carne fresca, de matança, de marcha, de consumação da força ${ }^{8}$. Mas o que a literatura quer destruir? Com sua força de destruição e sua dose de apocalipse, ela só pode mirar o fim, o fim do mundo. Mas que mundo seria esse? $* * *$

Déborah Danowski e Eduardo Viveiros de Castro trazem em seu livro Há mundo por vir?: ensaio sobre os medos e os
6. Referência ao título do texto de Maria Gabriela Llansol “O sonho de que temos a linguagem".

7. Referência ao título do livro Détruire, dit elle, de Marguerite Duras.

8. Fragmento da quarta capa do livro Emily L., de Marguerite Duras, e trata-se de um depoimento da autora à revista Nouvel Observateur. 
9. CASTRO; DANOWSKI. Há mundo por vir?, p. 25.

10. CASTRO; DANOWSKI. Há mundo por vir?, p. 26.

11. CASTRO; DANOWSKI. Há mundo por vir?, p. 26.

12. CASTRO; DANOWSKI. Há mundo por vir?, p. 26. fins, a noção de Antropoceno, nome para a possível era geológica em que vivemos e que teria tido início na Revolução Industrial e se intensificado desde o fim da Segunda Guerra Mundial. Ela é marcada pela insígnia do fim, o fim da espécie humana, pois o homem deixou de ser um simples agente biológico para se transformar em uma força geológica ${ }^{9}$, isto é, de um simples habitante, como qualquer outra forma que habita o mundo, o homem transformou-se em um ser capaz de interferir nas forças que movem o planeta. Essa "colisão dos Humanos com a Terra"10, segundo os autores, é paga com "a intrusão de Gaia no mundo humano, dando ao Sistema Terra a forma ameaçadora de um sujeito histórico, um agente político, uma pessoa moral ${ }^{11}$. O resultado disso é o que vemos atualmente: mudança climática, elevação dos níveis dos oceanos, extinção de inúmeras espécies, grandes períodos de estiagem, escassez de recursos naturais etc.

Tendo isso em vista, só é possível falar de um "mundo humano" porque o homem criou o seu, fora do mundo de Gaia, construindo uma espécie de redoma que "ao mesmo tempo nos separava e nos elevava infinitamente acima da Natureza infinita lá fora"12. Porém, essa redoma foi quebrada, sobretudo, ao longo da história do capitalismo, onde o homem começou a conceber Gaia menos como casa e lugar de partilha, e mais como um território a ser explorado, colonizado, comercializado e, assim, segundo Danowski e Castro, a humanidade tornou-se "uma catástrofe, um evento súbito e devastador na história do planeta, e que desaparecerá muito mais rapidamente que as mudanças que terá suscitado no regime termodinâmico e no equilíbrio biológico da Terra"13, o que faz com que os autores afirmem: "O Antropoceno é o Apocalipse"14.

O homem, portanto, criou para si um mundo incompatível com a sua própria existência e, por isso, viver tornou-se um estado de emergência, como se a todo instante fôssemos confrontados com a ideia do fim - finda-linh $a^{15}$. Nesse estado de emergência, restam-me, somente, mais perguntas: o que a literatura pode nos contar nesse mundo em que tudo parece já estar perdido, onde "a sensação de estarmos acordados possa ser um pesadelo a mais" ${ }^{16}$ ? Por que falar sobre literatura, se o mundo que conhecemos está prestes a ruir? O que escrever quando já não resta mais nada? Como retirar a literatura da redoma em que o homem a guardou e, uma vez fora dela, o que fazer para que ela não se perca nas mil e uma paisagens de Gaia? Será possível vislumbrar para ambos, literatura e homem, uma paisagem além do fim?

$$
* * *
$$

Biogaia ${ }^{17}$ é como Michel Serres propõe que vejamos o mundo, isto é, espaço ancestral onde terra e vida se misturam, "grito anterior a nossas línguas, sem elas, sob elas, fora delas, sob suas linhas, antes que brote o sentido do que digo." ${ }^{18} \mathrm{O}$ que
13. CASTRO; DANOWSKI. Há mundo por vir?, p. 27.

14. CASTRO; DANOWSKI. Há mundo por vir?, p. 35.

15. Noção formulada por Lacan respeito da personagem Antígona da tragédia homônima de Sófocles. Para Lacan, Antígona encontra-se "na-finda-linha", ponto extremo em que "a solidão definida em relação ao próximo está longe de se esgotar", por este estar situado em "uma zonalimite entre a vida e a morte [LACAN. O seminário, livro 7: a ética da psicanálise, p. 321]. Na zona limite de um "até", encontrase Antígona, "porque alguma coisa de para além dos limites da Até tornou-se para Antígona seu proprio bem que não é o de todos" [LACAN. O seminário, livro 7: a ética da psicanálise, p. 320].

16. CASTRO; DANOWSKI. Há mundo por vir?, p. 31

17. $O$ título do livro de Michel Serres, em francês, é Biogée. Sua tradução para Biogaia é de minha autoria. As traduções dos fragmentos desse livro foram feitas por mim, exclusivamente para este trabalho.

18. SERRES. Biogée, p. 43. 
19. SERRES. Biogée, p. 35.

20. SERRES. Biogée, p. 35

21. Esse "empacotamento" a que se refere Michel Serres tem isto é, o impulso excessivo do homem para dar sentido para coisas, seja porque "o sentido nos protege do medo" [SERRES. Biogée p. 38], seja porque. Blogee, p. 38.], seja porque palavra é a morte que a pasim, o mundo ina coisa pe tornar seu mais facilmente. Sobre esse movimento, Serres dirá: "Eu gostaria coisas livres de seus pacuras como se apresus pacotes, de se encontrarem nomeadas. [.. Assim, cada objeto iners. [...] Avsim, cám dormo iner, cava ta signos, um pouco su hoje, mil cartazes pouco como hoje, mil cartazes estourando de inus sujo, as piso un diluvio exc, as paisagens, ou melhor, porque o sentido, quase porque o sentido, quase nulo, iessa falsa lingua e dessas imanen baixas, forma um ponto de atraçâo irresistivel para nossos neurônios e olhos. Essa apropriação cobre de feiura a beleza do mun Biogée, p. 40 se pode ouvir dela não são mais que barulhos, ora violentos, como as trovoadas em meio à forte tempestade, ou a terra abrindo-se em um terremoto; ou fracos, como o murmúrio do mar em um dia de calmaria, ou o estalar de gravetos durante uma caminhada na mata. Porém, o homem, ao longo de sua história de colonização do mundo, distanciou-se de Biogaia, assumindo-se como sujeito detentor de um saber perigoso: $\mathrm{o}$ da nomeação. Nomear as coisas foi o que garantiu ao homem dominação do mundo, pois dar nome às coisas cria a cisão entre sujeito - aquele que nomeia e, portanto, detém o poder e objeto - aquilo que está sempre à mercê de quem o nomeou.

Ao longo da história do homem, que se confunde com a história do capitalismo, pode-se dizer que essa cisão entre sujeito e objeto é a mesma entre dono e propriedade, ou seja, ao dar nome às coisas, o homem transformou o mundo em sua propriedade. E, como donos, como sujeitos, segundo Serres, "nós pavimentamos o mundo [...] de objetos, assim nomeados por nós porque são jogados diante de nós, rejeitados, melhor, descartáveis"19 e construímos ao longo de nossa história uma "Terra-lixo" de "ar viciado, mares mortos, aves domésticas de bateria, patas soldadas no cimento, mundo imundo, lixão, emporcalhado por nós para nos apropriarmos dele." ${ }^{20}$ Assim, munido de palavras como se fossem armas, o homem promove uma espécie de "empacotamento" de tudo que habita o mundo, o que torna, cada vez mais difícil, ouvir o canto das coisas antes de serem nomeadas ${ }^{22} \mathrm{e}$ reduz a linguagem somente a uma convenção que se passa entre os locutores sem a consulta da coisa nomeada que, de repente, se torna propriedade de quem a recobre de imagens e sons. $^{23}$

Foi nesse movimento de "empacotamento" do mundo que ciência evoluiu, acentuando cada vez mais o abismo entre o sujeito e as coisas, sem se interessar em escutar o canto ancestral do mundo. É a partir dessa objetivação e em nome do que acredita ser sua função - a manutenção do poder do homem sobre as coisas -, que a ciência transformou o mundo em um campo de obras: pavimentou a terra; reduziu as florestas a parques, a reservas, ou as substituiu por plantações; poluiu os rios, os mares e o ar em uma velocidade inacreditável; fez do homem um animal racional, social e político, a ponto de fazê-lo confundir sua existência com a da ciência. Em outras palavras, os meios de conhecer, construídos pela ciência, são excludentes, pois excluem o mundo.

Para Michel Serres, as ciências duras encaixam-se nesse perfil, pois são aquelas responsáveis por tomarem "de um lado o sujeito pessoal ou coletivo, nobre, e do outro os objetos passivos e submissos, reduzidos a algumas dimensões de espaço, de tempo, de massa, de energia e de potência, quase nus, despidos, exangue" ${ }^{\prime 4}$ contrapondo-se às ciências da vida e da terra que, segundo o autor
22. Cf. SERRES. Biogée, p. 39

23. Cf. "Si le langage se réduit à une convention, elle se passa entre les locuteurs, sans consulter la chose nommée, devenue, du coup, propriété de ceux qui, ainsi, la recouvrirent de leur productions dessinées ou sonores". SERRES. Biogée, p. 41
EM TESE
BELO HORIZONTE
v. 21
N. 3
SET.-DEZ. 2015
ROCHA. Ética da paisagem
P. 90-103 
25. SERRES. Biogée, p. 35-36.

26. Refiro-me ao título do livro $O$ partido das coisas, de Francis Ponge. praticam uma maneira de conhecer mais partilhada, aberta, religada, onde aquele que conhece participa das coisas que conhece, renasce delas, tenta falar sua língua, escuta sua voz, respeita seu habitat, vive a mesma história evolutiva, encanta-se com suas narrativas, limita, enfim, por elas e para elas, seu poder e sua política, tão curiosamente nomeados pela cidade de onde se ausenta a Biogaia. As ciências da vida e da Terra costuram de novo o rasgo que separava o sujeito de seus objetos. Ouso dizer que elas se tornam humanas? Sim, eu sou o que eu penso e isto também sou eu; eu sou quem acaricio e o que eu sinto. Desafogado de suas prerrogativas exclusivas e decidido a ceder uma parte, o sujeito conhecedor se objetivisa, o objeto se cognitivisa. ${ }^{25}$

É preciso, portanto, tomar o "partido das coisas"26, como escreveu o poeta Frangis Ponge. Dessa maneira, podemos ver essa relação entre sujeito e objeto como um jogo, ou melhor, um objeu, palavra criada por Ponge e que promove, em um só golpe, o "encontro inesperado do diverso" - objeto $(o b)$, sujeito $(j e)$ e jogo $(j e u)$. Nesse jogo, no qual esses três elementos formam uma mônada - objeu - não há espaço para uma ciência que insiste em separar sujeito e objeto, para a qual o jogo confunde-se com a falta de rigor e pode ser interpretado como mero entretenimento.

Mesmo que Serres tenha dividido as ciências entre duras - aquelas que reforçam a cisão entre o homem e o mundo
- e as da Terra e da vida - mais próxima da partilha com o mundo-, insinuando que estas últimas se tornariam ciências humanas, acredito que o significante "ciência" ainda traz, muito forte, esse desejo de ruptura entre o homem e as coisas. Seja ela dura, da Terra, da vida ou humana, a ciência parece não ser compatível com o movimento proposto pela palavra criada por Ponge, objeu: colocar em abismo o objeto, a linguagem e, consequentemente, o sujeito.

Nesse sentido, não se pode mais falar de ciência, mas de experiência, pois o sujeito nomeia, mas também é nomeado. Este é o jogo, objeu: os nomes são lançados e apagados para serem criados novamente em outro lugar, em outro corpo, em outras paisagens. Nomear não é um jogo pertencente somente ao sujeito, pois aqui ele é atravessado por aquilo que está no exterior, o objeto, o Outro, e dessa maneira já não pode empacotar, engessar as coisas através das palavras, pois nesse jogo elas também são coisas e como tais podem ser renomeadas, a qualquer momento, mas também podem nomear o sujeito. Por isso, sujeito e objeto são sempre abismados e o mundo é, a todo momento, novo.

E não é a ciência o que sustentará esse objeu, mas a literatura, pois, como experiência, ela está sempre por se fazer, no limite do perigo - inclusive do perigo de se tornar uma ciência. A literatura pode ler uma árvore, sem precisar das informações taxonômicas de sua espécie, pois sabe, como 
27. PONGE. O partido das coisas. 2000, p. 137.

28. Cf. : "Je voyais comme la mer". SERRES. Biogée, p. 17.

29. Cf.: “Mon corps pense comme la Terre". SERRES. Biogée, p. 32.

30. Cf.: "Sempre me senti paisagem". LLANSOL. O senhor de Herbais, p. 195.

31. Cf. : “Eu brotei de sua água [do rio Garonne], da mesma água son eau, de la même jau naquit le monde"']. SERRES. Biogée, p. 29.

32. SERRES. Biogée, p. 29 atesta Ponge, que as árvores exprimem-se por suas poses, não podem guardar nenhuma ideia secreta, desdobram-se inteiramente, honestamente, sem restrição; onde quer que nasçam, por mais escondidas que estejam, só cuidam de levar a cabo sua expressão: preparam-se, adornam-se, aguardam que venham lê-las. ${ }^{27} \mathrm{~A}$ literatura pode fazer o homem ouvir a língua quase ininteligível da paisagem, que ele veja como o mar $^{28}$ e que seu corpo pense como a Terra. ${ }^{29}$ Ela faz com que o homem se sinta paisagem ${ }^{30}$ e que se coloque no mesmo ramo dos outros seres que habitam o planeta. A literatura faz com que o tempo tome outro caminho, pois o eterno não mais será marcado somente pela premissa de Heráclito, pois, na Biogaia, só nos banhamos no mesmo rio, nas mesmas águas, já que brotamos da mesma água de que brotou o mundo. ${ }^{31}$ Portanto, as águas que habitam o planeta são as mesmas e, por isso, "nos banhamos sempre nessa mesma água que corre, estatisticamente, cujo relógio circular marca menos o temporal que o eterno." ${ }^{32}$ Dessa maneira, a literatura não pode ser mesmo uma ciência, mas um saber anônimo e, portanto, um saber da terra, das águas, dos ventos, dos abismos, da flora, da fauna, do fogo... Um saber do vivo.

$$
* * *
$$

Eis que surgem, com a leitura e a escrita, as contaminações ${ }^{33}$, pois é assim que, sobreimpressos, esses dois espaços me aparecem: Vivo e Biogaia. Michel Serres definirá, assim, o que movimenta a Biogaia: "a Vida, Bio, sabemos, habita a Terra e a Terra, Gaia, se mistura à Vida." ${ }^{34}$ Mesmo que misturados, ainda vemos uma certa divisão entre vida e terra, no espaço construído por Serres, embora nele haja um esforço para abolir a hierarquia criada pelos homens em relação aos seres que habitam com ele esse espaço. Mas, mesmo assim, ainda há uma divisão, seja no âmbito da palavra, pois Biogaia é um substantivo composto o que reforça uma certa separação desses dois espaços, Vida e Terra; seja porque a terra ainda está separada da vida. É verdade que essa divisão é acentuada mais pela linha que demarca um litoral do que pelas linhas de uma fronteira, mas a cisão cria, ainda assim, uma distância, sempre presente, entre eles.

De um outro lado, temos o "vivo", escrito pelo texto de Maria Gabriela Llansol. Ele também abole as hierarquias entre os vivos - tudo o que faz esse lugar cumprir o destino do seu nome -, pois, na horizontalidade construída por essa não hierarquia, é possível a partilha das singularidades, diferentemente do que acontece na estrutura verticalizada do poder, em que, no lugar da partilha, sedimenta-se o movimento unilateral da imposição. No "vivo", terra e vida são uma coisa só, pois tudo é "vivo no meio do vivo" 35 . Aqui, todo vivo escreve, pois toda forma de encontro é uma escrita. Escrever, no vivo, é contaminar e ser contaminado pelo outro, é fazer das letras que restam desse embate os caminhos labirínticos de uma vida. E tais encontros não se
33. Refiro-me, aqui, à noção de "contaminação" formulada por Peter Pal-Pelbart. Segundo o autor, a "contaminação" e uma das formas da leitura, pois inscreve-se no movimento dos encontros e dos afetos, como podemos ler neste fragmento de Peter Pal-Pelbart: "Encontrar é afetar e ser afetado, conforme o ensinamento de Espinosa, mas é igualmente envelopar aquilo ou aquele que se encontra. Os heterogêneos se contaminam, mas cada qual também envelopa aquilo ou aquele que encontra, apodera-se de sua força, sem no entanto destruí-lo. [...] Em todo caso, num encontro, a partir da distância que Deleuze chamou de 'polidez' - Outy, de 'gentileza': Barthes, de 'delicadeza'; Guattari, de 'suavidade' -, há ao mesmo tempo separação, vai-e-vem

sobrevoo, contaminação,

envelopamento mútuo, devir recíproco". PAL-PELBART, Peter. Como viver só. 2008, p. 276.

34. Quarta capa do livro Biogée, de Michel Serres.

35. LLANSOL. Lisboaleipzig 1: o encontro inesperado do diverso, p. 120 
36. Cf. CELAN. Arte poética: o meridiano e outros textos, p. 55: é precisamente a de deste modo, falar também em causa alheia [...] falar em nome de um Outro, .... fal radicalmente Outro." dão somente entre humanos, pois, aqui, o homem é uma paisagem, isto é, ele é um "vivo", como qualquer outro, no meio do "vivo". E, nesse campo, uma ética desponta no horizonte: a ética da paisagem.

$* * *$

Por muito tempo a ética foi uma questão prioritariamente humana, já que se referia às formas de interação entre os homens em seu convívio social. Mesmo nos padrões éticos em pesquisas com animais, foi sempre pautada no sofrimento humano e, a partir disso, estabelecem-se as metodologias, os protocolos, que deverão ser seguidos para a melhor forma de intervenção nos corpos dos animais. É a partir do humano, sempre, que se pensa a ética. Porém, e se a pensarmos do ponto de vista de um radicalmente Outro ${ }^{36}$, como aponta Celan? Se pensarmos o homem como uma paisagem, como um vivo, o que isso nos diria? Como isso interferiria na ética? Que ética poderíamos pensar se concebermos o humano como mais uma paisagem dentre tantas outras que formam o planeta? O que diríamos da literatura, se a retirássemos da prisão que a submete ao homem, como se somente este escrevesse? Que passo a literatura poderia avançar, se ela não fosse mais sinônimo de ficção, mas uma verdadeira potência de criação de mundos no mundo? O que seria do homem se o céu desmoronasse? O que traria a ele essa espécie de apocalipse?
Primeiro, creio, ele poderia ver o mundo com seus olhos de paisagem e, então, veria o fosso profundo que criou entre si e a natureza e o ódio profundo que esta nutre pelo "homem, no ciclo do carbono, representar uma solução de facilidade e de felicidade relativamente a outras formas naturais e ser, cada vez mais, uma espécie autista, proliferante e conquistadora. ${ }^{37}$ Escrever com olhos e mãos de paisagem é perceber essa fenda aberta entre os sexos do homem e o da paisagem. Isso não quer dizer que a escrita, nesse ponto, sirva para tamponar essa fenda, ou desfazê-la, pois, dessa maneira, ela se configuraria como uma tentativa de volta a um tempo paradisíaco, como se pudéssemos passar uma borracha na história. Se tratarmos a escrita da paisagem como uma espécie de busca do éden, isto é, uma forma de apaziguar essa fenda construída pelo homem, trataríamos o texto como se fosse um texto ecológico, no sentido de trabalhar para uma certa pacificação entre homem e natureza o que, de certa forma, retiraria dele sua potência criadora de atrito. Além disso, como bem marca Llansol, "o texto, todavia, não é ecologista, não vê a natureza como um todo, como um fundo harmónico da espécie humana." ${ }^{38}$

Portanto, a escrita da paisagem não está ali para tamponar, destruir, diminuir ou maquiar a fenda que separa homem e natureza, mas para fazer da fenda um litoral onde cada vivo "é responsável por todo o vivo" ${ }^{39}$, isto é, se tudo no mundo
37. LLANSOL. Onde vais, DramaPoesia?, p. 187.

38. LLANSOL. Onde vais, DramaPoesia?, p. 187.

39. LLANSOL. Onde vais, DramaPoesia?, p. 187 
40. LLANSOL. Onde vais, DramaPoesia?, p. 187-188. escreve, cada vivo é responsável pelo texto que dá a ler. Essa responsabilidade por aquilo que se escreve - pois um escrito é como uma flecha rumo ao peito de quem o encontra - é um movimento ético e, porque não é um privilégio do homem e muito menos um dano adquirido, podemos chamá-la de ética da paisagem. Essa ética está bastante clara nesta passagem de Onde vais, Drama-Poesia:

o Jade é responsável, o pinheiro Letra é responsável, Prunus Triloba é responsável;

eu, Maria Gabriela Llansol, sou responsável pelo texto que dou a ler,

ser-se humano é evolutivamente um progresso de leitura mas não é um privilégio, nem uma superioridade, nem um dano adquirido,

\section{é um lado}

mais legível do que os outros para dar continuidade

e orientação à emergência do vivo no seio do universo. ${ }^{40}$

Porém, quando se fala de uma ética da paisagem, resta, calada, uma questão: como falar de algo intrinsecamente do campo do humano, a ética, fora dele? Ora, tal questão só se coloca assim, tão imperativa, porque ela é elaborada do lugar onde a fenda que separa homem e natureza ainda não é litoral e, portanto, não se encontra espaço para a emergência do vivo.
E aqui a emergência surge, pelo menos, em seus dois sentidos: aparecimento e urgência. É urgente que o vivo apareça para que possamos, como escreveu Llansol, abrir a ética às aranhas. ${ }^{41} \mathrm{E}$, com essa abertura, fica evidente que a questão ética não é exclusivamente humana, já que o humano só pode existir porque há um fora que o nomeia como tal. Assim, se o homem é, ele próprio, uma paisagem, e escreve como toda e qualquer outra forma que constitui o "vivo", a ética não deve ser um acontecimento exclusivo do homem, mas de tudo que, no mundo, escreve; se cada vivo é responsável por aquilo que dá a ler, ou seja, por sua participação na dança dos afetos que faz girar o mundo, a ética da paisagem é a responsabilidade de cada forma, humana ou não, sobre os traços, indeléveis, que deixa pelo caminho. Traços que contaminam e são contaminados pelas múltiplas formas do vivo. A ética da paisagem se configura, assim, como uma ética limite, litoral, na qual o homem só é homem quando é nada ${ }^{42}$, ou ainda, quando é paisagem. E, em uma ciranda sem fim, vai se traçando a narrativa infinita do vivo sobre a Terra.

$$
* * *
$$

Os traços escritos pelos corpos que formam o vivo - o texto - já se imprimiram sobre muitas superfícies. Muito antes do papel, eles já se imprimiam sobre as pedras, lascas de madeira, cascas de árvores, cascos de animais, ossos, placas de argila, folhas de palmeira, bambu. Sobre as tiras entrelaçadas
41. Referência a este fragmento de Os cantores de leitura: “Estava feliz a Ética. Um livro feliz era felicidade para nós. Bento, Baruch, Benedictus, Espinosa mantinha-se pobre entre os espectadores, $\mathrm{e}$ para chamar a si o perdão dos insectos que matara por curiosidade científica, abria a Ética às aranhas.

Com lucidez" (p. 154).

42. Referência à questão posta por Édipo, na tragédia Édipo em Colono, de Sófocles: "Hoje, que nada sou, volto então a ser homem?". SÓFOCLES. A trilogia tebana: Édipo Rei, Édipo em Colono e Antígona, p. 123. 
43. LLANSOL. O jogo da liberdade da alma, p. 12.

44. AGAMBEN. Ideia de prosa, p. 27. 45. AGAMBEN. Ideia de prosa, p. 27. 46. AGAMBEN. Ideia de prosa, p. 27. do caule de uma planta chamada papiro, os egípcios escreveram. Assim, também, fizeram os Maias sobre um papel produzido a partir da casca da figueira, o Kopó. Sobre tábuas de madeira revestidas por cera, corria o texto dos romanos. Também sobre a pele animal, pois dela se produzia o pergaminho, correu o texto, para depois passar para os cadernos e, muito tempo depois, para as telas digitais. Mas o que o suporte do texto pode nos dizer sobre ele?

Em $O$ jogo da liberdade da alma, Llansol escreve: "o caderno não é o escrevente do texto mas o lugar onde o texto aprende a materialidade do lugar por onde corre. ${ }^{13}$ Do texto portanto, também participa a materialidade dos suportes por onde passa, isto é, os cascos de tartaruga, as lascas dos troncos de árvores, as folhas, as penas que feriam as superfícies para imprimir as tintas do texto, as pedras. Tudo por onde correu faz parte do texto e, nesse sentido, o texto é, também, uma paisagem. Porém, esse movimento não é evidente, pois pode tornar turvas as imagens que o texto, pautado pela verossimilhança, preocupado com uma certa abstração da materialidade da língua e implicado com a indiferença em relação aos suportes por onde o texto corre, esforça-se em deixá-las tão cristalinas. O texto-paisagem segue outro cami-

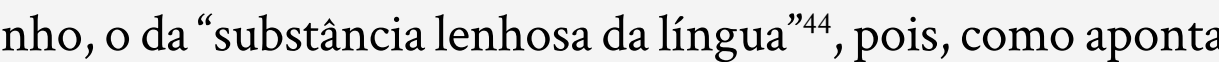
Agamben, "onde acaba a linguagem, começa não o indizível, mas a matéria da palavra" ${ }^{45}$, essa floresta fechada, como viam os antigos, onde se está livre das prisões da representação ${ }^{46}$. É nessa "substância lenhosa da língua" que se inscreve o litoral do mundo, onde as palavras não carregam somente conteúdos, sentidos, mas o cheiro por onde passaram, o desenho das letras, os sons impressos de acordo com um ritmo, as texturas e as nervuras impregnadas no seu corpo pelo atrito com as múltiplas superfícies sobre as quais passou, o sabor singular que imprimem no paladar, as chagas e as carícias que deixam sobre a pele e a beleza e o espanto com que nos brindam, ao nos confrontar com a sua nudez.

Para receber esse texto, para lê-lo, é necessária uma certa operação que, ao lado de Maria Gabriela Llansol, chamaria de "vegetalização". Esse movimento foi descrito nesta bela passagem de Ardente texto Joshua:

Vegetalizar é uma operação de inervar, tornar lúcidas as nervuras do texto, operação delicada que pode tornar turva a

\section{imagem}

que surge

e se transforma em texto.

É mais fácil compreender quando se olha o texto com a lin gua dos pássaros, sons, ritmos, morfemas,

que ora são língua, ora são imagem, ora são este corpo que escreve, ora são nada

diz-se, por vezes, palimpsesto, 
47. LLANSOL. Ardente texto Joshua, p. 74.

\section{Cf. LLANSOL. O livro das} comunidades, p. 10: "Escrever vislumbra, não presta para consignar. Escrever, como neste livro, leva fatalmente o Poder à qué um Corpo Cem que

\section{mas não}

compreender um texto é como compreender um cão, uma previsão do tempo,

ou seja,

é aceitar que não se fala,

que se não compreende, excepto pela companhia,

é não confiar no tempo que fará

vê-lo como prometido e como incerto

como nadas objectivos que podem ser o algo concreto a que meu corpo se liga ${ }^{47}$

Tornar lúcidas as nervuras do texto, deixar claras as marcas da paisagem que ele carrega e o fazem ser um corpo "cem memórias de paisagem"48, ou seja, com menos sentido e mais terra, mais água, mais cão, mais fogo, mais matéria, é a operação de "vegetalização". Ela nos permite ler um texto através da companhia, pois, não passando pelo sentido, a leitura se dá pelos afetos e, da mesma maneira que fazemos com um cão, uma árvore ou uma tempestade, lemos esse texto: pelas memórias indeléveis que ele deixa na paisagem.

$$
* * *
$$

Ainda sobre as palavras, sua "substância lenhosa" e sua parte vegetal, ouçamos Lacan:
[...] a Coisa só se apresenta a nós na medida em que ela acerta na palavra, como se diz acertar na mosca. No texto de Freud, a maneira pela qual o estranho, o hostil aparece na primeira experiência da realidade para o sujeito humano é o grito. Esse grito, eu diria que não precisamos dele. Gostaria aqui de fazer referência a algo que está mais inscrito na língua francesa do que na língua alemã - cada língua tem suas vantagens. Em alemão, das Wort é, ao mesmo tempo, a palavra e a fala. Em francês, a palavra mot tem um peso e um sentido particular. Mot é essencialmente nenhuma resposta. Mot, diz La Fontaine a certa altura, é o que se cala, é justamente aquilo para o qual nenhuma palavra é pronunciada. As coisas que estão em questão - e que alguns poderiam contestar-me como sendo por Freud colocadas num nível superior ao desse mundo de significantes sobre o qual lhes digo o que ele é, ou seja, o verdadeiro móvel do funcionamento no homem do processo qualificado de primário - são as coisas enquanto mudas. $E$ as coisas mudas não são exatamente a mesma coisa que as coisas que não têm relação alguma com as palavras. ${ }^{49}$

É preciso tempo para alguma coisa nascer. Tempo e palavras. Na voz de Lacan, foram palavras o que encontrei. Encontrei-as mudas, com a Coisa a acertá-las como uma flecha. Porém, encontro-as agora, na leitura, nuas, mudas, mas não sem voz, não sem corpo. É de fato uma dádiva que cada língua tenha seu valor, pois assim como Lacan
49. LACAN. O seminário, livro 7: a ética da psicanálise, p. 71
EM TESE

BELO HORIZONTE

v. 21

N. 3

SET.-DEZ. 2015

ROCHA. Ética da paisagem

P. 90-103 
aprofundou-se no francês a partir do alemão, posso avançar na língua portuguesa e tocar na palavra como se tocasse na superfície movediça e inconstante de um espelho d'água. A palavra, para mim, como um dia me escreveu Maria Gabriela Llansol, "vem sempre à tona de água”. Com Lacan, recebo-a muda. Porém, na minha língua, sinto o impulso de desdobrar a palavra "muda". Assim: de um lado a mudez e do outro a muda, como se diz de uma planta. A palavra é também muda - potência vegetal. Ela é muda, pois está prestes a nascer - já nascida. Também é muda porque todo nascimento é precedido de um longo silêncio. A palavra também muda, isto é, sempre pode ser outra coisa. E em direção à palavra-muda que conduzo essa passagem de Lacan.

A palavra-muda carrega consigo o silêncio da paisagem e por isso, está sempre a ponto de ser outra coisa. Está sempre a nascer - ininterruptamente. Porque não é semente, não traz o peso da moral que salgaria o solo por onde cai Definitivamente, não se pode confundi-la com "semente", pois, assim, faríamos como Padre Antônio Vieira que, ao semear a palavra-semente, desejava criar uma alma para aqueles que julgava não a possuirem, mas o que fez, de fato, fo contribuir para o extermínio daqueles corações selvagens que encontrou por aqui. Extermínio este que perdura até hoje. É preciso também dizer que a palavra-muda não catequiza, pois cresce sempre no campo do fora e é pelo toque, e não pela oratória, nem pela moral, que ela pode alcançar o corpo dos homens.

Com ela, a natureza deixa de ser transcendente e, não estando além nem aquém, ela se encontra no meio de nós. Talvez, a palavra-muda possa nos fazer enxergar o que lutamos, a todo momento, para esquecer: o fato de que somos apenas uma forma de ser, dentre milhares que habitam o planeta, e que não há, nisso, algum privilégio. A palavra-muda, talvez, nos ajude a conceber a literatura não mais como "o que consiste mesmo em dar 'forma' a uma visão da realidade pelo artista que retira da natureza a sua inspiração e experiência, recusando-a ou transfigurando-a." ${ }^{50}$ A palavra-muda não retira nada da natureza, porque faz parte dela, escreve com ela e nos aponta a vida, o vivo. E, nesse movimento, ela impõe uma ética - a ética da paisagem -, pois não concebe o homem como um ser destacado dos outros que caminham sobre o mesmo chão.

Portanto, a palavra-muda reforça a ideia de que a literatura não é um privilégio do homem, pois ela está em toda parte, dado que tudo no mundo escreve, sempre escreveu. É verdade que o homem ficou, por muito tempo, preso em si mesmo, exilado pela própria fenda que criou entre si e a natureza, mas, com ela, literatura e homem são levados a ler tudo o que antes lhes parecia mudo e invisível, são levados à força de uma descoberta: ler e escrever com a paisagem.
50. COUTINHO. Notas de Teoria Literária, p. 28. 
Toda revelação, toda descoberta traz consigo uma força apocalíptica. A cada dia corremos o risco de deparar-nos com o inesperado e, diante disso, somos convocados à imobilidade, fonte do medo, ou a continuarmos a marcha, mas em outro ritmo, com outros passos, por outros caminhos. A ética da paisagem surge, então, como uma força de revelação. Mirando na "substância lenhosa da língua", ela faz o homem questionar o exílio em que se colocou em relação à natureza. Lembra-lhe que o poema é escrito pelos traços não só do humano, mas do húmus, dos rios, dos pássaros e dos vermes que habitam o planeta. Fazendo emergir o vivo, a ética da paisagem reforça a potência anônima da literatura e a mistura com as matérias que constituem o vivo Com ela, a leitura é mais uma experiência sensorial que intelectual, e, assim, podemos sentir as texturas, os sabores, o canto das palavras nuas e mudas. A literatura, aqui, cede lugar ao canto das florestas que, em meio ao caos, reúne um concerto de vozes que também devem contar a história do mundo. A ética da paisagem lança o homem para dentro do vivo e, aí, ele poderá ouvir o canto lento e silencioso da escrita dos dias e com ele traçar o melhor caminho face à violência de revelação de um apocalipse, pois o mundo sempre chega, ao final de cada dia, ao seu fim. Para nascer de novo.

\section{REFERÊNCIAS}

AGAMBEN, Giorgio. Ideia de prosa. Trad. João Barrento. Belo Horizonte: Autêntica, 2012

BJÖRK. Jóga (excerto). In: Homogenic. Brasil: Polygram, 1997. CD.

BRANCO, Lucia Castello. A pedra dura ao luar - O caderno branco. InComunidade, ano 3, ed. 27, out 2014. Disponível em: http://www.incomunidade.com/v27/art bl.php?art=4. Acesso em: 04 abr.2015.

BUESCU, Helena Carvalhão. Paisagem literária: imanência e transcendência, Revista Colóquio/Letras. Lisboa: Fundação Calouste Gulbenkian, n. 179, jan./abr. p. 9-18, 2012.

CASTRO, Eduardo Viveiros de; DANOWSKI, Déborah. Há mundo por vir?: ensaio sobre os medos e os fins. Desterro [Florianópolis]: Cultura e Babárie: Instituto Socioambiental, 2014.

CELAN, Paul. Arte poética: o meridiano e outros textos. Trad. João Barrento. Lisboa: Cotovia, 1996.

COUTINHO, Afrânio. Notas de Teoria Literária. São Paulo: Vozes, 2008.

DURAS, Marguerite. Détruire, dit-elle. Paris : Les Éditions de Minuit, 1969

DURAS, Marguerite. Emily L. Rio de Janeiro: Nova Fronteira 1988.

LACAN, Jacques. O seminário, livro 7: a ética da psicanálise. Rio de Janeiro: Jorge Zahar, 2008. 
LLANSOL, Maria Gabriela. Ardente texto Joshua. Lisboa: Relógio D'água, 1998.

LLANSOL, Maria Gabriela. Contos do mal errante. Lisboa: Assírio e Alvim, 2004.

LANSOL, Maria Gabriela. $\mathbf{O}$ jogo da liberdade da alma. Lisboa: Relógio D'água, 2003.

LANSOL, Maria Gabriela. O livro das comunidades. Lisboa: Relógio D'água: 1999.

LLANSOL, Maria Gabriela. O senhor de Herbais. Lisboa: Relógio D'água, 2002.

LLANSOL, Maria Gabriela. O sonho de que temos a linguagem

Revista Colóquio/Letras. Lisboa: Fundação Calouste

Gulbenkian, n. 143/144, jan. 1997. p. 5-18.

LLANSOL, Maria Gabriela. Onde vais, drama-poesia?. Lisboa: Relógio D'água, 2000.

LLANSOL, Maria Gabriela. Os cantores de leitura. Lisboa: Assírio e Alvim, 2007.

PAL-PELBART, Peter. Como viver só. Catálogo da $27^{a}$ Bienal de São Paulo. Rio de Janeiro: Cobogó, 2008, p. 267-276.

PONGE, Francis. 0 partido das coisas. Trad. Adalberto Müller Jr., Carlos Loria, Ignácio Antonio Neis, Júlio Castañon Guimarães, Michel Peterson. São Paulo: Iluminuras, 2000

SERRES, Michel. Biogée. Paris: Éditions Le Pommier, 2013.
SOFOCLES. A trilogia tebana: Édipo Rei, Édipo em Colono e Antígona. Trad. Mário da Gama Kury. Rio de Janeiro: Jorge Zahar, 1998 